\title{
The Empty Square of the Occupation
}

\author{
Marcelo Svirsky Cardiff University
}

\begin{abstract}
This paper is an attempt to implement Gilles Deleuze's theory of the series and the event, and the related function of the empty square (as formulated primarily in The Logic of Sense), in relation to the geopolitical regime comprising 'Israel proper' and the system of occupation in the West Bank and the Gaza Strip. The purpose of this exercise is to help establish a practical access to Deleuze's philosophies, and to offer a clinical account of the Israeli occupation of the Palestinian territories.
\end{abstract}

Keywords: Israel/Palestine, occupation, Deleuze, empty square, series, event

The regime of Israeli occupation of the Palestinian territories of the West Bank and Gaza, following the Six Day War of June $1967,{ }^{1}$ has become increasingly theorised, especially since the outbreak of the first Palestinian intifada (in Arabic, literally 'shaking-off', or 'revolt') in 1987. By deploying nuts and bolts from Deleuze's conceptual 'toolboxes', my aim is to proffer an analysis of the event of the occupation that frees us from prevailing views of the system of relationships between Israel and the Palestinian people. Specifically, the paper joins recent critical research deconstructing consensual representations of the conflict, representations that for decades have divorced the Israeli socius and its internal organisations of hobbled citizenship for non-Jews from the oppressive system of occupation in the territories. Hitherto, Zionist representations of the conflict have been successfully territorialised into ideological and political arenas, so as to mobilise most of the Jewish citizenry into the daily management, at both micro and macro levels,

Deleuze Studies 4.3 (2010): 381-411

DOI: $10.3366 / \mathrm{E} 1750224110001030$

(C) Edinburgh University Press

www.eupjournals.com/dls 
of oppression against Palestinians, and to disengage the international community from adopting a deep critical standpoint towards Israel. By injecting Deleuze's theoretical tools into critical readings of the conflict, we hope to contribute to ongoing interventions aimed at deterritorialising the workings of the desiring-machines involved in the social production of the real in the region between the Mediterranean Sea and the River Jordan. To this end, in the main I examine critically three recent and significant works on the occupation: Eyal Weizman's (2007) Hollow Land, Neve Gordon's (2008) Israel's Occupation, and Ariella Azoulay and Adi Ophir's (2008) This Regime Which is Not One: Occupation and Democracy Between the Sea and the River (1967-). In addition, the analysis will refer to a highly recommended recent volume which compiles diverse studies of the 'prevailing modalities of the occupation regime in various periods and their order of significance'. Rather than convey a uniform image of the occupation, these studies 'highlight disparate rationalities and mechanisms of power whose heterogeneity reinforces the overall effectiveness and perseverance of this regime' (Ophir et al. 2009: 22).

These critical works will serve here as a platform for highlighting the traits of the 'system' of the occupation-or, in Deleuze's terms, 'how the series connect to make the structure' (see Deleuze 1990, 1994, 2004). As Lecercle explains, for Deleuze, the series 'define a field of problems, and their terms are correlated through a relation subject to constant variation and displacement' (Lecercle 2002: 108). What we are interested in is the sense of the event of the occupation as a surface effect produced by that displacement, which Deleuze explains in terms of the circulation of a paradoxical element - which needs to be explained here contextually-crisscrossing and zipping together the series of the structure of the occupation. This element is what Deleuze refers to in The Logic of Sense as the 'empty place or square' (also named 'the aleatory point', and, in Difference and Repetition, 'the dark precursor') - whose function is to explain the points of contact between the series and how they interconnect (Deleuze 2004: 184-9). As Deleuze puts it:

Given two heterogeneous series, two series of differences, the precursor [the empty square] plays the part of the differenciator of these differences. In this manner, by virtue of its own power, it puts them into immediate relation to one another. (Deleuze 1994: 119)

This seemingly structuralist tint to Deleuze's philosophy is nevertheless consistent with his emphasis on univocity, and with the critiques he and Guattari make of biunivocal structuralism (in both volumes 
of Capitalism and Schizophrenia, particularly in their critique of the despotic signifier and the 'binary logic of dichotomy', which dominates psychoanalysis and linguistics). In fact, this approach serves to highlight the production of sense taking place-since 'sense is produced by nonsense and its perpetual displacement' (Deleuze 1990: 71)-thereby keeping the structure open to constant movement and deterritorialisation and staving off stratification and the hierarchical functions of a signifier. Here it is worth bearing in mind that by examining a particular series of historico-political relations, what is productive, in terms of resistance, is to understand the sense of these relations not as 'a phenomenon of degradation representing a deviation from the true order', but as an involutionary process of becoming (Deleuze and Guattari 1987: 237-8) in which forces change in nature (intensity) and a real difference is actualised (Deleuze 1994: 231-46, 252-6).

Accordingly, the occupation cannot be thought of as an infection or disturbance of the normal functioning of the formally democratic regime of 'Israel proper' (assuming that, when it finally ends, the regime will be cured of the disease), but must rather be understood as a device which, by maintaining a fluid communication with the regime of 'Israel proper', both explains the Jewish state's practices and meanings and opens them to contestation. As we shall see, the 'empty square' of the occupation appears as emerging from the various combinations of historically and spatially changing modalities of the oppression of Palestinians across the 'Green Line', ${ }^{2}$ creating intricate relations of abandonment (cf. Agamben 1998).

\section{From 'Hollow Land' to 'One Regime'}

Eyal Weizman's Hollow Land (2007) offers a good starting point, mainly in view of the attention his work has gained among Deleuze researchers. Weizman is among the non-resident Israeli academics who have been openly critical of the occupation project. In a nutshell, his book expands upon the evaluation of the 'matrix of control' of the Israeli occupation, beyond the traditional bounds of political territoriality, to the vertical dimension-extending, that is to say, not just to the land surface, but to the underground domain and to the airspace as well, all of which play a part in the logic of segregation from, and control of, the Palestinian people and its land. According to Weizman, Israel's elastic geography of nomadic domination responds to multiple and diffused power sources, in relation to which architecture fulfils a functional 
role. Indeed, Weizman contends that the occupation-as a plane of production - has developed architectural properties. The reason we lack an intelligible reading of the occupation, he says, is because we overlook verticality. He builds on the concept of the 'politics of verticality' to outline the main patterns of a three-dimensional domination, compounded by a patchwork of sealed 'islands' of Palestinian territory which-like the subterranean water aquifer and the militarised space above-fall under Israeli control. An intricate web of roads, tunnels and bridges has been woven to secure Israeli colonies-which are generally sited on the summits of mountainous terrain-within the Palestinian territories. Moreover, Israel uses roads and land confiscation to curb Palestinian development, and to restrict Palestinian movement by introducing a 'forbidden road regime that [limits] the inhabitants' access to major traffic arteries in the West Bank' (Gordon 2008: 137). As a consequence, the diverse boundaries of the conflict are revealed at varying topographical latitudes (Weizman 2007: 12).

It is in this context that the subterranean and aerial Palestinian resistance in Gaza-specifically, the tunnels to Egyptian territory for the smuggling of goods and arms, and rocket attacks on Israeli towns near the border-should be understood. ${ }^{3}$ For Weizman, this 3-D logic multiplies Palestinian geography 'to separate the inseparable' (Weizman 2007: 15). This is the same logic of partition which, as Ilan Pappe argued recently (Pappe 2009), has weighed upon both Palestinians and Israelis like a curse, condemning them for nearly half a century to seeing the conflict exclusively in terms of partition. Ultimately, we are left with a hollowed-out land inhabited in layers, and controlled through them.

From a Deleuzian point of view, Weizman's work has become known among scholars not only for the vocabulary he employs to describe the Palestinian space (elastic territories, multiple and diffused sources of power, nomadic domination, vertical strata, connecting flows, and so on), but mainly for an unexpected implementation of Deleuze and Guattari's spatial concepts. 'Walking through walls' was a trademark of the military campaign waged by the IDF (Israel Defence Forces) against the West Bank city of Nablus in April 2002 (during the second intifada), amidst claims that it was based on a particular implementation of critical theory, including works by Deleuze and Guattari. Terms such as 'inverse geometry', 'nomadic terrorists', 'swarming and infestation', 'non-linearity' and 'deterritorialisation' became part of the IDF's lexicon during the planning and execution of its offensive, which involved moving military units through domestic interiors-'punching holes 
through party walls, ceilings and floors'-and avoiding the use of streets and conventional urban open spaces (Weizman 2007: 185-6). As Shimon Naveh, a former co-director of the IDF's Operational Theory Research Institute (since closed), explained:

Several of the concepts in A Thousand Plateaus became instrumental for us [in the IDF] ... allowing us to explain contemporary situations in a way we could not have otherwise explained. It problematised our own paradigm... Most important was the distinction [Deleuze and Guattari] have pointed out between the concepts of 'smooth' and 'striated' space... [which accordingly reflected] the organisational concepts of the 'war machine' and the 'state apparatus'. In the IDF we now often use the term 'to smooth out space' when we want to refer to operation in a space in such a manner that borders do not affect us. (Cited in Weizman 2007: 200-1).

For Naveh, theories do not have a soul, nor do they strive for utopian socio-political ideals ('theory is not married to socialist ideals'). $\mathrm{He}$ recognised that theories are based primarily on methodological principles, and focused on their capacity 'to disrupt and subvert the existing political, social, cultural, or military order' (cited in Weizman 2007: 215). Naveh is correct-nor should his claim be regarded as particularly outrageous. In fact, the case is illustrative. The point is not what can be done with theory or literature-which in any event cannot be foreseen-but how our actions relate to our desiring-production. The expectation that a 'correct' reading of Deleuze and Guattari might transform IDF officers and Zionist politicians into anti-segregationists or even humanists is a notion drawn from a classical Marxist interpretation of thought and action. It is not false consciousness that impedes revolutionary action, but rather the type of desiring-machines at work, and the entrapment of desire by interest (cf. Buchanan 2008: 38-133). In the case of 'walking through walls', the unconscious (collective) libidinal investment of the IDF assemblage 'continues to invest the former body, the old form of power, its codes, and its flows' (Deleuze and Guattari 1983: 347). In this instance, 'desire is enslaved to a structured molar aggregate' - namely, Zionist colonialism-and invested with the changing forms of power deployed by the system of occupation (348). Thus, there is nothing particularly revolutionary in the IDF's reading of Deleuze and Guattari-not because it facilitated domination and killing, but because the syntheses that it allowed for were already predisposed to given and fixed military and political interests, rendering the desiringproduction paranoid and reactionary (366-7). In other words, it takes more than reading Marx to become Che Guevara. 
To return to the issue at hand, Weizman-like other scholars of the conflict before him (Benvenisti 1984, 1986, 1987; Kimmerling 1989; Peled and Shafir 2002; Yiftachel 2006; Raz-Krakotzkin $2007)^{4}$ - 'define[s] the limits of the discussion in terms of the boundaries of the space of control' (Azoulay and Ophir 2008: 371), and refers to a relationship or dynamic of dependence between the Israeli regime within the Green Line ('Israel proper') on the one hand, and the Israeli military regime in the occupied Palestinian territories on the other. However, it is a mistake to limit the discussion of the regime to the boundaries of Israel proper, since 'there is no such geopolitical entity' (371): the real geographical realm of Israel proper extends beyond the Green Line as far as the River Jordan, as does its economy and its politics. As Azoulay and Ophir explain, the problem is that these scholars uncritically accept the premise that the two entities are somehow separate, thereby ignoring the effects of the occupation on the regime of Israel proper. As a result, they

perpetuate the prevailing view that the Palestinian territories constitute an 'outside' where everything that occurs-however appalling morally and politically-does not compel us to re-conceptualise and analyse the Israeli regime as a whole, and can therefore be described without reflecting upon the fundamental characteristics of the Israeli regime. (Azoulay and Ophir 2008: 46-7)

This circumscribed view of the effects of the occupation is also apparent in Gordon's Foucauldian analysis of the occupation. It is most notable, for example, in his book's final passage, where he suggests that a solution to the conflict hinges solely on the emergence of Palestinian sovereignty in the territories (Gordon 2008: 225)-or, as he puts it, on re-connecting the Palestinian people with its land. As I hope to establish in this paper (apart from placing the focus on problematisation rather than resolution), if we wish to deal more effectively with the event of the occupation and reach a more positive problematisation of the conflict for all concerned, we must link the processes and changes occurring within the territories with those within Israel proper. As Azoulay and Ophir point out: 'The occupation of the Territories in 1967 represents a rupture-line in the history of Israel, because as a result of this event a radical change took place in the Israeli regime' (Azoulay and Ophir 2008: 395).

The event of the occupation, as we shall see, obliges us to revise our concepts and understanding of the nature of the Israeli regime if we wish truly to grapple with this event on the political level. One facet of this effort must involve new formulations of what can be said in 
our discourse concerning the conflict: we must intersect and make more immanent connections between the Palestinians of the West Bank and Gaza, and Israeli citizens and residents (Palestinians, Jews and others), and between their respective material and cultural interactions.

This, in fact, is the analytical innovation introduced by Ariella Azoulay and Adi Ophir in their book This Regime which is not One (2008). Beyond a mere demonstration that the two regimes are somehow connected, they demonstrate how the oppressive regime of Israeli occupation (in the West Bank and Gaza) and the formal democracy in Israel proper, form a single political regime consisting of two discrete, but symbiotic, systems of control. According to Azoulay and Ophir, despite their dissimilarities, these two political systems have become increasingly integrated since the start of military occupation in 1967 into a single body of domination. As they explain:

At the end of the 1960s the state of affairs of the Occupation became a national project; in the 1970s it became larger; and at one point at the beginning of the 1980s the project was institutionalised and became a regime of its own, almost differentiated but not totally separated from the ethnodemocratic regime in place within Israel of the pre-June 1967 borders. (Azoulay and Ophir 2008: 395)

By thoroughly investigating the system of domination of the 'one structure' and embarking on a comprehensive counter-actualisation of the given, the main purpose of these two writers is to decipher the conditions that allowed for the emergence of such a hybrid political construct. They also maintain that, after four decades of military occupation, the Israeli political regime has doubled in size in all respects, through a carefully engineered form of production of separation between its two parts-one maintained by proximity and interconnection-compounding the impact of this 'inclusive exclusion' upon the Palestinians (Ophir et al. 2009). In the following section, I shall try to show how a Deleuzian framework might expand upon Azoulay and Ophir's main contention vis-à-vis Israel's schizoid redoubling in size, and proceed from there to enhance and expand the optical resolution of their analysis, before finally offering a clinical diagnosis of the state of forces of the 'one regime'.

\section{Two That Are 'One'.}

Given that Azoulay and Ophir's book has so far appeared only in Hebrew, I will briefly outline its structure and rationale. 
The fundamental question addressed by its authors concerning the Israeli project for Palestine after the partition war of 1948 -and especially after the conquest of the Palestinian territories in 1967-is 'how the institutionalised and prolonged domination over the Palestinians has shaped and changed the Israeli regime' (Azoulay and Ophir 2008: 19).

Based on this question, the researchers aim at shedding light on the nature of the Israeli regime that is simultaneously 'one' body and yet more than one. The study sets out from two central premises: first, as noted above, that 'the debate cannot be limited to Israel proper, since such a geopolitical entity does not exist' (Azoulay and Ophir 2008: 371); and, second, that: 'The occupied territories are an integral part of the Israeli system of domination, [involving] a relentless effort to preserve them as an 'outside' ... this being the Israeli regime's primary concern' (57).

The authors' task is to distil the general principles of the Israeli regime, which must be seen as extending 'from the Mediterranean Sea to the Jordan River'. This undertaking involves two major methodological measures: first, to describe empirically how the occupation regime works, by focusing on 'the forms of Israeli domination over the Palestinian territories' (Azoulay and Ophir 2008: 13); second, to link these modalities with their reverberating practices within Israel proper, and to synthesise their abstractions of the system of the occupation with the more general and known patterns of the ethnocratic regime within Israel proper.

What distinguishes Azoulay and Ophir's work is the way in which they present the problem of the occupation. While drawing on Foucault - without doing so overtly - their proposed analysis also owes much to Deleuze. First, by creating new concepts, the work removes restrictions that restricted the scope of critical understanding in previous analyses. For instance, they point out that while most scholars agree that the central distinction to be taken into account when conceptualising the Israeli regime is the ethno-national distinction between Jews and nonJews, they omit the significant category of non-citizens, without which the formation of Israeli mainstream subjectivity cannot be understood (Azoulay and Ophir 2008: 377-9). Second, they distinguish between the actual and the virtual, allowing the conditions of the boundaries of the structures in question to be deduced, and thereby enabling a mobile understanding moving between the two realms.

Azoulay and Ophir's analysis does not offer programmatic solutions to the problematic of the occupation; rather, they search for what emerged to become the conditions of a project (the occupation) in the 
course of its evolution over four decades. These conditions set out the 'solubility' of the problem of occupation in a Deleuzian fashion: they point to the significant changes in the historical 'graph' of the occupation, to the 'zeros' of its function (cf. Deleuze 1994: 171; 180-1). These are the points where distributions in the given diverged, illusions of identification and significations took root, and the occupation was established as the new possible of the Zionist-Palestinian structure. More importantly, it becomes clear from Azoulay and Ophir's analysis that the significant points of inflection in the 'problem' of the occupation do not exhaust the problem itself but should be seen as a manifestation of what has varied, and how it has done so, throughout the observed systems - in the form of a single infinite series of answers to a problem that is itself constantly evolving.

Azoulay and Ophir's book is a splendid exercise in poststructuralism. ${ }^{5}$ Their starting point is Foucauldian: two dominant discourses on the event of the occupation are deconstructed in the book; the first concerns the occupation's temporariness (a temporal discourse), and the second, externality (a spatial discourse). The temporal discourse dressed up the occupation with a temporality that became indefinite by promoting a sense of imminent resolution, based on talk about 'peace for territories'. This linguistic space allowed for a professed Zionist readiness to discuss the terms of ending the occupation, while in fact standing in for, or perpetually deferring, any actual discussion about that ending. At the same time, the spatial discourse succeeded in placing the occupation outside the daily lives of most Israelis - as a distant space, physically and mentally, making it possible to bracket the territories away from the Israeli collective consciousness (Azoulay and Ophir 2008: 27). As Gordon points out, 'The overall objective was to weaken internal resistance to the Occupation, and since rhetoric does not always have to avoid contradiction, the Occupation was presented as simultaneously temporary, moral, and nonexistent' (Gordon 2008: 7). The main point Gordon stresses here is that in the discourse of the Occupation, it became a temporary project and simultaneously exterior to the State of Israel.

The intersection of the respective discourses of temporariness and externality is what gives the occupation the discursive force that has preserved it as a 'normal' or 'invisible' form of living (Gordon 2008: 49). These discourses explain how the impact of the occupation on the production of Israeli cultural, political and social life is minimised or eliminated. For instance, we find no reference to the occupation as such, as a system of colonial occupation, in the increasingly militarised 
educational system (where it is explained as a space being negotiated for the sake of all involved); ${ }^{6}$ in the perennial debates over the condition of Israel's 'democracy' (in which the occupation is presented as an ongoing test of a still-vibrant democracy, rather than its antithesis); in the discourse regarding peace and national security (where the occupation is presented as a 'necessary evil', for which the Palestinians themselves are responsible); or in discussions in which ethnic segregation (which has deepened since the occupation began) is presented as both justified and as a self-evident necessity.

These two suspensions have given the occupation project both life and legitimacy: if it is 'outside' Israel proper, then it does not reflect on Israel as a whole; and if it is temporary it is tolerable. This is the consensus that Azoulay and Ophir tackle in their book and which has resulted in two interlinked and appalling actualisations: the various modalities of oppression of the Palestinians across the Green Line, and Israeli normalcy. To examine this unfortunate situation critically, we must go beyond the limits imposed by the occupation's discourses and modes of thinking, modes of dominance, and general productions.

In terms of the operational political regimes involved, the status quo in the land between the Mediterranean and the River Jordan is as follows: within the Green Line-'Israel proper'-there is a sovereign system operating along the lines of a sophisticated ethnocracy (Yiftachel 2006), which skilfully manipulates democratic tools and techniques to its own ends; the areas beyond the Green Line-the Palestinian territories held since 1967 - are subject to an oppressive colonial-military regime. The stark contrast between these two entities underscores the 'outside-ness' of the occupation and is related, according to Azoulay and Ophir, to two fundamental classifications which are also in play: first, a territorial division between the area within the Green Line and the occupied Palestinian space beyond; second, a division between two discrete systems of subordination: of citizens on the one hand (Jews and non-Jews - the latter being mainly Palestinian), and non-citizens (Palestinians) on the other. These distinctions, however, are merely plain and unadorned statements of empirical fact, and do not attest to the qualitative properties of the systems of domination. In fact, if this was all there was to the matter, they would point to a simple congruence of the 'territorial' and 'subordinate' classifications, rendering the detaching of the territories from Israel proper a redundant exercise. However, this is not the case.

The two classifications are not congruent because matters such as land, people, apparatuses of control and the market economy, do not 
form separate planes of production divided neatly along the Green Line-contrary to the claims made by promoters of the so-called 'Security Barrier' (the Wall), now running through the West Bank, and of the barbed-wire fence along Gaza. Rather, Azoulay and Ophir's main argument should be read as follows: the occupation project has evolved in the Sea-to-River region as a dynamic system of domination, in which intertwining libidinal flows - of authority, of people, of material things, of cultural ideas, and of economic investments-run in both directions, from Israel proper into the Palestinian territories and vice versa. Particular forms of domination - of the Palestinians - arise from this organisation. As a result, trying to examine the two regions as two separate and unconnected entities is akin to dismembering a body and studying each part in isolation, in a bid to understand the function and properties of the anatomy as a whole. No interpretation could be more mechanical or more empirically wrong about Israel/Palestine.

By contrast, what emerges from a holistic examination of the Seato-River space, beyond the formal and tangible political systems, is the overall body that we do not normally see-the structure-which has no official existence as a recognised political entity, but which nevertheless impacts in a very real way on its subjects, given the reciprocal workings between its two constituent parts. The Sea-toRiver regime is a manifestation of the order of the structure - a third order, defined by Deleuze as the symbolic (Deleuze 2004: 171-3). For Deleuze, the symbolic realm is the outcome of choices, selections and omissions of particular relations - 'a process where the symbol implies a rearrangement of relations in structures' (Williams 2005: 58). In this instance, the rearrangement occurs in the organising body of relations and connections emerging from the ways in which the occupation has evolved since 1967. This body is the latest stage of evolution of the historical encounter between Zionist immigrants-settlers and the native Palestinian people at the end of the nineteenth century, and provides the structural conditions for the real for Israelis and Palestinians. As a structure, it 'is defined as a necessary condition for the transformation of the thing' (54). By understanding this structure as a source of becomings for Israelis and Palestinians, we might 'read' more correctly how this body evolves and may be transformed. To put it another way, this understanding converts the conditions of impossibility into the conditions of possibility. In practical terms, it frees us from the limited and fanciful view that the occupation and its wider repercussions may be easily undone by a peace accord following a political resolution-as well as from the consensual model of the 'two states' solution. One 
way to pose the question raised by Azoulay and Ophir might be: can Israeli citizenship, cultural habits and governmentalities be regarded in detachment from the systems of control of the West Bank and Gaza? From the point of view of the 'structure', the answer must be no.

\section{A Regime of Fluxes}

From the outset of the occupation in June 1967, Israeli domination has been applied concurrently but differentially to territories and subjects, 'making a clear distinction between the land it had occupied and the people who inhabited it' (Gordon 2008: 6). What has evolved is a system of 'confiscation without integration' involving

a series of mechanisms... thus developed to expropriate the occupied land without fully annexing it, while numerous apparatuses and practices were introduced to regulate and manage the lives of the Palestinians without integrating them into Israeli society. (Gordon 2008: 6) ${ }^{7}$

This distinction, however, is incidental to the more fundamental principle of the territorial distinction, as we said, between the occupied land and Israel proper (Azoulay and Ophir 2008: 46). On the one hand, a complex legal patchwork system for governing the Palestinians has been repeatedly amended, incorporating elements of 'Ottoman, British Mandatory (particularly the emergency regulations of 1945), Jordanian and Egyptian law (depending on the region), and Israeli military orders' (Gordon 2008: 27). At the same time, the Israeli colonies ${ }^{8}$ and settlers on the West Bank and Gaza have always been subject to Israeli law as if they resided within the Green Line (8). In other words, settlers, soldiers and other Israelis within the Palestinian territories have been 'extra-territorialised' and invested with 'personal jurisdiction', carrying the Israeli law on their person, as it were, within the territories, thereby expanding the functions and spaces of action of Israeli law. This embodiment of the law, in the most literal sense, has turned movement into a unit of analysis and of biopolitical application. ${ }^{9}$ In other words, to the question of whose body it is, these expansions have added the spatial question of 'where'.

Moreover, the occupation is 're-imported' on a daily basis into Israel proper through those self-same bodies (settlers, IDF soldiers and officers, clerks, private companies' employees, and -ironically - also left-wing activists 'visiting' the territories for purposes of protest and support) - who by their very presence and the roles they play reiterate the 
'doubled' or expanded nature of the Israeli regime. As Gordon describes it:

Settlers are constantly travelling both within the OT [occupied territories] and to Israel, commuting to work, taking children to school, going shopping, and visiting friends. While these private trips are no doubt part of the settler's daily routine, simply by travelling within the OT the settlers fulfil several functions. (Gordon 2008: 139)

To manage the Palestinian territories-complementing the military administration which acts as the executive branch-Israel deployed various formal administrative ministerial committees made up of senior officials from government ministries, and-since 1981-the Civil Administration, which was appointed as the governing body for all civil affairs (Gordon 2008: 30). On the economic front, the relationship that has arisen between Israel proper and the Palestinians has been 'marked by a series of constraints and restrictions that hindered the development of an independent Palestinian economy' (70)-the better to promote Israel's needs and interests. One hallmark of this interdependence is the securing of the Palestinian territories as a captive market for Israeli goods (Azoulay and Ophir 2008: 97; Gordon 2008: 70-5). Although the occupation 'opened up' new labour opportunities for Palestinians from the West Bank, East Jerusalem and Gaza (mainly in services), the dependency it engendered proved to be a double-edged sword, as it enabled Israeli employers - with the state's blessing-to exploit Palestinian workers as cheap labour, which in turn helped trigger the swift growth in the Israeli economy following the 1967 war (Gordon 2008: 66).

As Gordon explains, Israel has implemented various modes of economic power to manage the Palestinian population and economy: in the first decades for example, Israel used 'pastoral power' to promote a certain degree of Palestinian prosperity to discourage organised national resistance (Gordon 2008: 62-9): 'in exchange for their partial economic incorporation, the Palestinians had to contain their political desires' (82). But management here should not be understood in terms of Foucauldian confinement; rather, domination was based through the monitoring of moving bodies: a continuous control of Palestinians within the whole geography of the Israeli regime (cf. Deleuze 1995: 174-5). This is how, slowly, open fields, roads, streets, homes and workplaces - on both sides of the Green Line-became a multiplicity of sites of control.

The territories' colonial dependency has been compounded by the way Israel has expropriated Palestinian land (for colonies, military 


\section{Marcelo Svirsky}

bases, security, and roads infrastructure) and natural resources (mainly water), at the expense of Palestinian farmers (Gordon 2008: 127-8). It has also had disastrous consequences for the prospects of economic prosperity and a sound economy developing in the West Bank and Gaza. From the time of the first intifada-and, more acutely, since the second one-Israel has placed severe restrictions on the movement of Palestinian goods and workers $(33-40 ; 185),{ }^{10}$ reducing the Palestinian economy to a precarious state of affairs and the Palestinians themselves to destitution. ${ }^{11}$ The occupation became not only a means for the IDF to stimulate the Israeli economy, but for the colonies and the military regime to become targets of economic investment by Israeli private companies seeking to profit from servicing the settlers and the IDF system of control (electricity, communication, construction, and so on). All in all, as Gordon describes,

At a certain point the distinction between government expenditures within Israel proper and expenditures in the OT was expunged from the annual budget, in effect transforming the entire area from the Jordan Valley to the

Mediterranean Sea into one economic unit. (Gordon 2008: 8; see also 63)

The incorporation of the territories into the Israeli economy has ultimately led to their annexation in all but name. This includes controlling Palestinian imports and exports (in contravention of the 'Paris Accord Custom Union' of 1994); ${ }^{12}$ skewing competition with Israeli products to ensure that the Palestinians are a captive market; imposing restrictions on Palestinian business and industry development to favour Israeli companies, who benefit from tax relief and the protection of the law for their exploitation of Palestinian workers; worsening restrictions on movement of Palestinian goods and labour through a complex regime of permits, and so on. No one today can imagine the Israeli economy without the territories. ${ }^{13}$

This state of affairs did not change substantially as a result of the Oslo process (which began in 1993) and the resulting Accords. Indeed, as Gordon maintains, these should in reality be seen as the 'outsourcing of the Occupation' (see Gordon 2008: 169-96), since they reorganised power by making the Palestinian Authority a proxy of the occupation regime. Although the establishment of the Palestinian Authority created a semblance of sovereignty (see Azoulay and Ophir 2008: 167-72), in fact, for the Palestinians themselves it has doubled the burden on a personal level: the Israeli occupation has given up nothing of its general spatial dominance, while ushering in a new regime of controlled human 
movement, and slicing the territories into hundreds of separate enclaves and Jews-only spheres of movement.

In addition, land colonisation did not cease but was transformed in inventive new ways (for example, through more land appropriations for Jews-only roads and separation artefacts, and through what Israel ingeniously refers to as 'illegal outposts', which in reality extend the colonial fabric while portraying the illusion of a rule of law befitting a democratic state). ${ }^{14}$ In fact, the only area where the Israeli regime has truly abdicated its responsibility is in relation to the civil welfare of Palestinians, which it has handed over to the Palestinian Authority while simultaneously undermining the latter's ability to provide welfare and manage the population (Gordon 2008: 192). In the final analysis, the Palestinians have found themselves facing two kinds of Israeli control-direct and indirect-depending on the type of territory they live in. ${ }^{15}$ In effect, it might be said that Oslo silently 'killed off' the first intifada, while contributing a great deal to the normalisation of the occupation (182). This description of the various ways and means of oppressing the Palestinians in the territories shows 'that suspension of law and the forsaking of life do not completely overlap' (Ophir et al. 2009: 23): to deny citizenship and rights, Israel implemented power-regimes that activate law in different forms ('a tapestry of regulations, procedures, and decrees'), making clear that abandonment is not necessarily produced by scarcity of care (letting die), but rather the opposite, through active action. This is how irresponsibility, abandonment and perfection are held together. Azoulay and Ophir's critique of Agamben on this point is clear:

The abuse of life at the hands of the ruling power is not due to some withdrawal of the law, but occurs thanks to a savage proliferation of legalities and illegalities and the creation of an extensive judicial patchwork that has no lawfulness of its own and that keeps changing the law itself, the regime's authorities and immunity, and the subject's own status before the law. (Azoulay and Ophir 2009: 114)

For Israelis, if anything clear-cut has emerged from the Oslo Accords, it is that they have bestowed legitimacy on the time-honoured notion of separation and partition not only as the logic by which space must be governed, but as the moral and political horizon to aspire to.

All in all, the project of occupation has created mutually supportive metastases (Israel proper and the territories), born as such due to the continual movement of material, human, legal, political, economic and cultural fluxes between them. In addition to these two spatial 
paths of fluxes, there are innumerable other, related, fluxes, such as those determining the type of relationships between the State of Israel and its Palestinian citizenry, and fluxes forging connections beyond the territorial space of the 'Sea-to-River' regime (for example, internationally supported forms of resistance). All these fluxes are instances-particular (here-and-now) actualised sub-structures-of an unconscious structure: at this point I suggest that the structure explaining the functioning of the Zionist-Palestinian system or the 'one' Israeli regime in the Sea-to-River region corresponds to, following Agamben, a structure of abandonment (Agamben 1998: 2005). ${ }^{16}$

In 'How Do We Recognize Structuralism?', Deleuze states that every structure is a virtual multiplicity of serial coexistence, consisting of elements held by differential relations that continue into the determination 'of singular points that constitute a space corresponding to these elements' (Deleuze 2004: 176-7, 179-80, 182). Many series are involved in the production of this structure of abandonment: from the previous description of fluxes alone we can attest to the coexistence of politico-juridical, biological, economic and territorial series. The elements of the politico-juridical series, for example, include the rule of law, political rights, political subjects and political spaces (the camp and the public realm). The interrelations of these elements, and the differential relations between this series and the others, 'determine the nature of the beings and objects which come to realize them' (177). In the capitalist mode of production, for instance, exploitation and alienation are explained by the historical differential relations of property and appropriation holding between the symbolic elements of the labour force, the worker, nature, money and the segregated space of production (178). We will now go on to ask how the differential relations between the series of the Zionist-Palestinian system create values and attitudes (effects) that confer a relation of abandonment upon the structure.

This means we must 'account for the very particular presence of [the] structure in its effects, and for the way in which it differenciates these effects, at the same time as these latter assimilate and integrate it' (Deleuze 2004: 181) - in our case, then, we must retrieve the structure of abandonment (of Palestinians) of the 'Sea-to-River' regime by analysing its effects in terms of the actual impact upon life within those boundaries. Indeed, a structure not only 'lives' in the virtual, but in accordance with the logic of reciprocal causality 'also differentiates the species and parts, the beings and functions in which the structure is actualized' (180). The virtual multiplicity constituting the structure of the 'one' regime is embodied throughout the matrix of fluxes running across the 
Green Line, 'according to exclusive rules, always implicating partial combinations and unconscious choices' (179). These fluxes carry and distribute parts and objects - such as the contested land, the soldier, the Palestinian farmer, the settler, the Jewish-citizen, the Palestinian citizen, the Palestinian worker, the economic relations, the colonies, the forms of authority and dominance, the forms of resistance, and so on - which actualise differential relations between the series by arranging themselves differently within each flow, forging different roles and functions and ultimately manifesting certain subjectivities.

From the point of view of the two metastases, the main conclusion is that since 1967, the occupation has broadened Israel's range of governmentability beyond the Green Line, and that the Line itself has since become a differentially permeable membrane through which a new political regime has developed. What is taking place is a dual dynamic of accentuation and erasure of the Green Line. On the one hand, the way in which the educational system within Israel proper has portrayed the occupation as a complete outside, the economic integration, the 'extension' of Israeli law embodied within the settlers and the colonies themselves, the colonisation of Palestinian land, labour and water-these have all but erased every vestige of the Green Line as a traditional frontier. On the other hand, the separation wall, the 'menial jobs without benefits and security' (Gordon 2008: 89), the regime of permits, closures, curfews and other instruments installed to control Palestinians' movements and to confine them, and the Palestinian resistance-all underscore the continuing existence of the Line. The changing location (always moving checkpoints for example) and varying porosity (changing the permit regime to allow passage according to age, profession, hours and so on) of the membrane striates the space of the in between' structurally, but not specifically - terrorising the entire passagezone.

The endless traffic between the two parts of the regime attests to the 'extensions' produced by each flow. This perspective is revealing of the nature of this particular form of military occupation: it has evolved not only as a profusion of systems of control, surveillance and resistance, but also as a host of systems of mutual absorption between the territories and Israel proper. ${ }^{17}$ The respective extensions of the two sub-structures together form a particular kind of connection. We have seen how they are joined together by the fluxes that render them interdependent; it is, however, a relation normalised by depicting the occupation as an 'outside' that should be disregarded. For most Israeli Jews, 'the part [i.e., the occupation regime] of the whole [the regime between Sea and 
River] is grasped as extrinsic to the whole, and this is exactly how it is included' (Azoulay and Ophir 2008: 390). 'Most Israelis do not know the other part of the moon', as Azoulay and Ophir explain, yet it is nevertheless one and the same moon. This is how 'normalcy' has been incrementally established since 1967: upon a productive plane (political, legal and economic) which has fused together the Sea-to-River space in a particular manner, while at the same time presenting the occupation as something divorced from everyday life in Israel.

Azoulay and Ophir dub this situation inclusion through separation, or inclusive separation; more recently Ophir et al. (2009) have named it inclusive exclusion - that is to say, what is separated is retained, because otherwise:

If the separation is completed, the project will come to an end and the regime will collapse, leaving just the two entities that constitute it... [conversely] if the separation is terminated, the regime will also collapse, since the two entities that constitute it will merge into one. (Azoulay and Ophir 2008: 391)

This is how 'placing the territories on the outside in fact amounts to their incorporation within the State of Israel' (Azoulay and Ophir 2008: 26). The logic of 'inclusive exclusion', therefore, is what prevents the structure from slipping either into complete annexation or into complete withdrawal (187). It is this suspended state that explains the productive aspect of the regime and its changes over time. The production is the result of a continuing struggle between two kinds of forces - one generating separation, while the other enhances the degree of involvement and contact between the two parts of the regime (190-2). 'The regime of the Israeli state is therefore the structure formed from the particular amalgamation of two different regimes under one roof' (330)-hence the label, 'two that are one'. In other words, there is no such thing as an Israeli or a Palestinian socius as a separate entity -there is only a common Israeli/Palestinian socius.

In this way, the occupation regime has transformed the government of Israel into the 'Sea-to-River' government, and-more crucially-its citizenry into an electorate for that government. 'The Israelis are also part of this regime as citizens - not only because for over forty years they have voted in 'free and democratic elections' for governments that persist in expanding and cultivating the system of domination in the territories', but mainly because their civic habitus became an instrument of the occupation (Azoulay and Ophir 2008: 400). 


\section{The Empty Square of the Occupation}

It follows that Israel cannot be contemplated on its own-nor can the system of occupation. Nevertheless, there is no formal structure between the Sea and the River in the shape of a unified regime, but rather a series of hybrid, disjunctive syntheses of fluxes. The dynamic of 'inclusive separation' suggests that 'the structure contains a paradoxical object' (Deleuze 2004: 184)-something that signals that the project is unfinished and lacks a clear and final identity, something that 'has become a permanent feature of the occupation regime and of the apparatus linking the two regimes' (Azoulay and Ophir 2008: 395). This object leaves behind the real as something unresolved, in a state of dynamism and discomfort. Something clearly connects the two regimes, and runs through them, displacing elements and generating properties in its path. This object, the paradoxical object of the structure, is the empty square: it does not remain in a fixed position, but is constantly moving; nor is it occupied continuously by the same element - thereby preventing the formation of an identity based on elements. It neither belongs to, nor is fixed by, either series, but is present in all of them dynamically. Its content can never be fully identified and, according to Deleuze, it prevents our minds from merging series together. In the case at hand, it has indeed been successful: although by rights we ought to, we tend not to think of the regime lying between the Mediterranean and the River Jordan as a single entity.

Is it possible for us to 'identify' the element maintaining the dynamism of the structure-the empty square of the occupation? What is it that ceaselessly slices through the series, crossing them and yet still capable of depicting their communication? What is this object that has enabled the regime's effective doubling in size, and its syntheses?

To answer this question, I shall examine the way the symbolic series are manifest through the fluxes running between the two metastases. Firstly, I adopt Azoulay and Ophir's distinction between 'the governed condition'-that is, the formal-legal relationship of the subject to the state, and 'participation'-namely, how hegemony and political dominance are constructed, and by whom (Azoulay and Ophir 2008: 379-81). Both dimensions highlight Agamben's structure of exception in politics. Citizens and non-citizens are ruled or governed differently, while the dimension of participation is absent in non-citizens but differentiates-in Israel-along ethno-national lines. Within the territories, citizenship eclipses ethno-national differences, since it is the Palestinians' non-citizen status that defines their 'governed condition' 
and establishes the distinction and relevance of the sphere of citizenship. Within Israel proper, the ethno-national categorisation relies upon citizenship differences in 'participation'-a practice that is the raison d'être of the Jewish state.

Secondly, on the 'game-table' of the occupation, the shape of the empty square is governed by the combination or interdependence of 'the governed condition' and 'participation'. It is present in the fluxes running to and fro between the two regimes, and has varying values at different coordinates of time and space. The initial distribution at the start of the occupation in 1967 was the starting point. At that time, the Palestinian citizens of Israel were only a year into the new regime that followed the revocation of the military government they had lived under since 1948. So while Palestinian subjects within Israel proper were passing from meticulous control by the state to a more mild biopolitical subjectivation (Lustick 1980; Ghanem 2001), Palestinians in the newly occupied territories were about to become a subject of disciplinary power (Gordon 2008: 23-47): different 'rulings', and different 'participations' - for a divided people by one regime.

But as the occupation evolved, and fluxes started crossing it back and forth, elements began changing places in the series, producing a navigable border which in effect doubled the scope of the Israeli regime. The empty square communicates between the series by communicating between the flows running from Israel proper into the territories and back again, and its singularity resides in what it enables us to think - the transformations and becomings occurring throughout the series within the actual order of things. Thanks to the empty square, the series reverberate off each other (Gil 2008: 410) in a communication based on their intersections as streams of differences (not as identical items of a species), which in fact is the principle of emission of singularities, or of events (Deleuze 1990: 51). This works as follows:

Once communication between heterogeneous series is established, all sorts of consequences follow within the system. Something 'passes' between the borders, events explode, phenomena flash, like thunder and lightning. Spatiotemporal dynamisms fill the system, expressing simultaneously the resonance of the coupled series and the amplitude of the forced movement which exceeds them. (Deleuze 1994: 118)

The relations between the series cause the two parts of the regime to make contact and merge, synthesising subjects and objects into a single body by displacing the system of subordination (of citizens and non-citizens) from matching the territorial distinction (between the two 
The Empty Square of the Occupation 401

sub-structures), thus generating a productive tension - or the 'problem' of the occupation. However, although this displacement defines the problem, it does not determine it fully, attempting as it does both to approach and to separate. In this context, we must remember that 'problems are defined by the way structures do not fit together and yet have internal drives to achieve that fit' (Williams 2005: 64).

While keeping in mind that power applies itself ubiquitously, shaping bodies and subjects everywhere and not only at one of its 'ends', ${ }^{18}$ we might follow Gordon's example and argue that the communication between the series since 1967 has been constantly changing and expressing the transformations in the 'modes of power' and 'modes of resistance' between Israel and the Palestinians. 'During the occupation's first years', explains Gordon, 'Israel emphasised disciplinary power and bio-power...' while during the last years, and especially since the second intifada, Israel plays 'the more traditional mode of sovereign power-shifting from a politics of life to a politics of death' (Gordon 2008: 11-13; 115; 206-8). This 'shifting emphasis on one mode of power rather than another... [and] the interactions, excesses, and contradictions within and among the controlling practices and apparatuses... and Palestinian resistance' explains the 'changing nature of the occupation' (15). ${ }^{19}$ For example, 'with the adoption of the separation principle' following the Oslo Accords and the modes of power implemented in response to the second intifada, the nature of the Green Line changed from a comparatively 'open membrane' to a border that is 'normally closed' to Palestinians, 'transforming the OT into a container of sorts' $(212 ; 180) .{ }^{20}$ On the other hand, since 1966 Palestinians in Israel proper have been increasingly challenging the promises of Israeli democracy by levering the discourse of rights and, lately, of multiculturalism for the sake of creating a more inclusive regime (Smooha 1990, 1997; Adalah 2007).

The relationship to the law (by way of another example) also changed regarding the territories: until September 2000 Israel controlled the occupied inhabitants primarily through the application of draconian laws (including the legalisation of incarceration of political prisoners, of deportations, house demolitions, torture, extended curfews and other forms of collective punishment), but, according to Gordon, the period since the second intifada has been characterised by a more violent abandonment of the Palestinians (Gordon 2008: 205). Uncertainty is assured by making it impossible for those in the territories to internalise the law, as Azoulay and Ophir explain: 'What the Palestinian learns in an encounter with the regime in one venue... does not teach him or her 
what to expect in other encounters in other venues' (Azoulay and Ophir 2009: 115). Although we would like to move through a less arborescent model of the law, it seems that this somehow rhizomatic character does not enhance life. Here, once more, we have another striking example of how the IDF implement Deleuze and Guattari's conceptual tools. In parallel, as we shall see in the next section, a new assertive approach to laws having a direct impact on Palestinians in Israel proper (in terms of land, housing and loyalty to the state) has been adopted lately, marking a departure from the former policy of hidden discrimination.

The mechanisms for discipline and control of the Palestinians across the Green Line are integrated into a single plane of production of oppression, but operating from different strata, and through different assemblages, so as to shape different but connected subjects. As we can see from the examples, the pairing of 'the governed condition' and 'participation' is based on the kind of conditions Deleuze set for the empty square: when appearing in one place as an excess, it is manifested elsewhere as an absence (Deleuze 1990: 51). This enables the series to communicate in terms of reciprocal determination, and to flow as two branches of the same structure. The empty square is the element that attests to the historical sets of selections, omissions and syntheses in the actual-the symbolic element of the structure, the infrastructure. It is the event of the occupation that leaves its mark upon the series, changing them and their relations of sense, thereby 'making sense' of the problematic nature of Western democracy.

\section{A Triangle of Subjectivities}

In examining this developing state of affairs, Azoulay and Ophir are right to claim that 'the domination of the occupied territories is the context in which the government has acted since 1967, and whose constraints have governed its handling of outlying issues' (Azoulay and Ophir 2008: 26; original emphasis). The domination of the territories rapidly changed from yet another national task in 1967 into a project that became 'the fundamental matrix through which the government operates' (Azoulay and Ophir 2008: 26). As a result, it was not only the international community that started to view Israel through the occupation, but the regime itself embraced that outlook as well. At some point since the occupation began, four forces merged together, with irreversible consequences for the Israeli political and social regime, namely: unwillingness to incorporate the occupied Palestinians; persevering on the distinction Israel made between 
The Empty Square of the Occupation 403

Palestinian inhabitants and Palestinian land; the emergence of the criterion of citizenship to differentiate between occupied Palestinians and the Palestinians within Israel proper; and the devastating force of the ethno-national logic inside Israel proper. The syntheses between these forces crystallised the differences between occupied people and citizens, and created a relation of conceptual and practical interdependence between the three significant subjectivities emerging in the Sea and River space: on the one hand, the Palestinian subject-the non-citizen and pariah of the regime (exploited worker and oppressed political subject); his antithesis - the Jewish-Israeli citizen (Azoulay and Ophir 2008: 109); and lastly, the Palestinian citizen within Israel (living under a relationship of ethnically alibied abandonment). This triangle of subjectivities (conceptual rather than geometrical) embodies the empty square that actualises 'the governed condition-participation' pair, enabled by a twofold harnessing of the non-citizen status of the occupied Palestinians and the handicapped citizenship of those inside Israel. This connection points to what appears to be the most significant change introduced by the system of occupation in the Zionist-Palestinian structure since the assembling of the Zionist collective desire to 'cleanse' Palestine at the start of the national project in the early years of the twentieth century (Svirsky 2010), and the brutal widespread cleansing of the land in 1948-9 (Pappe 2006). Specifically, this change means that denying citizenship to the Palestinians in the territories reinforces ethnic restrictions within Israel; to put it more bluntly, the former became the logic of the latter. Viewed from the other side, we might say that for the regime-and for most Jewish Israelis - thinking about the prospects for the role the Palestinians citizens should play is almost never detached from the fact that the Palestinian territories are being occupied. The resonance between the Israeli public's acceptance of and acquiescence in the occupation on the one hand, and with the devalued character of the citizenship held by Palestinians within Israel on the other, is a consequence of the 'ethnic sounding-board' reverberating between the Sea and the River, and evident in all walks of life-be they legal, geopolitical, educational, social or cultural.

A few examples might illustrate the range and depth of this phenomenon. For many years, one of the state-controlled radio stations has broadcast a 15 -minute programme called 'Friends and Family-Lost and Found' five times a week. People phone in to ask for help in finding friends and relatives with whom they have lost touch. Like many other shows on Israeli radio and television, the intended audience might be Hebrew or Arabic native speakers - or so one would 
assume - but in reality the programme is broadcast in collaboration with the Jewish Agency and the Central Zionist Archive, and serves as a means for seeking out Jews who went missing during the Holocaust or its aftermath, or with whom contact was lost during one of the waves of immigration to Israel. No one in his right mind-Jew or Palestinian-would imagine a Palestinian citizen phoning in for information on his or her relative lost during the Nakba. ${ }^{21}$

Nowhere is this 'ethnic normalcy' more plainly evident than in housing policy, particularly when it comes to rural housing. Under the notorious 'Judaisation of the Galilee project' (launched in the early 1970s), many small and expressly Jews-only communities were established in Israel's northern region in a blatant attempt at demographic engineering (Yiftachel 1993, 1999, 2006). Following riots in the region in October 2000-in which 12 Palestinian citizens were killed by the police - and in the face of threats by Jewish local authorities, the Israeli Ministry of Defence allocated funds 'to increase security', which meant enclosing the Galilean Jewish communities behind iron fences and electrically operated gates. This kind of physical landscape is reminiscent of that of the Jewish settlements in the territories - thereby further diminishing the significance of the Green Line and highlighting the occupation's expansion into the ethnic project taking place within Israel proper (Azoulay and Ophir 2008: 421).

To enshrine in law the existing ongoing exclusion of Palestinian families from these bourgeois rural communities, the Knesset has lately initiated legislation on the subject, echoing the internal codes of admission set by 'acceptance committees' established by the communities themselves.

In contrast to the old manner of concealed discrimination (which implied a measure of discomfiture), this time ethnic segregation is being overtly stratified (and justified) in a manner similar to the practice in the territories. The occupation has infiltrated and shaped action, thinking and subjectivities ${ }^{22}$ in other areas as well. This is clearly demonstrated in the amendment to the Law of Citizenship of 2003, ratified four years later by the Supreme Court. ${ }^{23}$ Although passed as a temporary provision, it has been re-enacted every year since then (echoing the discourse of temporariness used to perpetuate the occupation). According to this amendment, the right of equality in starting a family is seriously curbed for Palestinian Israeli citizens. On the pretext of 'security', it precludes a Palestinian Israeli citizen from applying for citizenship for their spouse if the latter is a (Palestinian) resident of the territories. Consequently, if a family wishes to stay together in such marriages, its only option is to 
The Empty Square of the Occupation 405

move to the territories, or abroad. Such is the plane produced for them by the occupation and Israel proper.

Increasingly, the sound of abandonment reverberates and connects Palestinians across the Green Line: although separated by the criterion of citizenship, this is what governs the relationship between the two populations of Palestinians, between their hobbled citizenship within Israel proper, and their managed abandonment within the territories. It is no wonder, then, that the emergence of a civic-democratic habitus in Israel lies far beyond actual conditions. The Israeli regime of citizenship/non-citizenship is a blunt example of how abandonment is exercised as a defining feature of contemporary politics - a toxin with no antidote. In the case of the Palestinian citizens of Israel, the ethnic barrier is what prevents them from becoming full and equal citizens, and it is structurally underpinned by another form of abandonment, namely, the non-citizen status of the Palestinians in the territories. In other words, given the latter exception, the former becomes logical and plausible: for the Palestinians in Israel proper, the realistic alternative to their situation is not full integration and egalitarianism, familiarity and proximity to the regime, but rather non-citizenship. Thus, the occupation must be understood not simply in terms of the radicalisation and endless restrictions placed upon the Palestinian citizens of Israel, but as the total alienation of occupied Palestinians so that the ethnic-based exclusion of the Palestinian citizens within Israel proper may be more easily ignored, managed and justified (Azoulay and Ophir 2008: 386). In this way, the realms of citizenship and non-citizenship are bound together, inasmuch as one defines the other, and the argument that the Israeli regime and citizenship cannot be understood without reference to 40 years of Israeli occupation becomes evident.

\section{Epilogue}

In fact, Israeli democracy should be seen as the expressed form of the event that is the occupation; democratic life in Israel proper takes place amidst the exploitation and the total exclusion of the Palestinians from the territories (Azoulay and Ophir 2008: 431). To put it another way: 'the regime of the Occupation is an extreme instance of a known structural property of democratic regimes: the existence of a significant backyard of a ruled population that takes no part in the shared administration of public life' (Azoulay and Ophir 2008: 446).

The notion of 'democracy's backyard' is a clear echo of Agamben's structure of exception, and yields a fruitful discussion of what needs to 
be transformed. The backyard may be democracy's hell, but it is also that which defines the democracy. Abandonment and exploitation are a given in this space. In the case of the Israeli regime, it refers both to the regime's split nature (it is not inclusive and yet universal) and to its physical boundaries (from Sea to River). It is embodied in the differences in how the various communities in that space are ruled - the aforementioned empty square, or pairing of 'the governed condition' and 'participation'. In the region bounded by the Mediterranean and the River Jordan, this square, 'the backyard', moves and takes on varying shapes and contents. The territories function as the regime's significant backyard, but at the same they are also the immediate backyard of the Israeli colonies. Additional backyards exist within Israel proper. The linking between the various backyards is what absolves the regime of responsibility for the harm done to the people populating them. By this method, the regime succeeds not only in putting the backyards out of mind, but in laying responsibility for them elsewhere.

Azoulay and Ophir's contribution to this discussion is to highlight how the exclusion of Palestinian citizens within Israel proper is seen as a fault that need not be remedied - or in other words, 'the alienation of the occupation as a regime is the flip side of the alienation of the nonJewish citizens in Israel proper' (Azoulay and Ophir 2008: 442). At the same time, the reciprocal relationship between distance and proximity, and between citizenship and non-citizenship, in the Sea-to-River region, accentuates their contrasts, providing yet another significant sign left to us by the event of the occupation.

In light of all the above, it would be wrong to think of 'internal' changes within Israel proper-such as the notion of equal rights for Palestinian Israeli citizens-as taking place independently of events in the territories. The 'internal' must be seen as extending from the Mediterranean Sea to the River Jordan, given Israel's success in establishing 'dominance over the Palestinian non-citizens as a selfevident feature of the Israeli regime' (Azoulay and Ophir 2008: 430).

If the empty square of the occupation represents the boundaries of the structure, then only by introducing new differences within these boundaries can the structure be changed. Any substantive change in the structure of the Israeli regime must involve new deterritorialisations of the dyad 'the governed condition' and 'participation', whereby the struggle is taken up by all individuals in that jurisdiction, in a bid to change the form, the limits and the content of the regime in the area under Israeli control. ${ }^{24}$ 


\section{Notes}

1. As a result of the war, Israel also conquered East Jerusalem, the Golan Heights and the Sinai Peninsula (see note 2).

2. The term refers to the 1949 armistice lines agreed between Israel and Egypt, Jordan, Lebanon and Syria following the 1948 war (known in Israel as the "War of Independence'). The Green Line refers to the border separating Israel from the territories of West Bank, Gaza, the Sinai Peninsula and the Golan Heights, before they were captured during the Six Day War of 1967. The Sinai Peninsula was returned to Egypt as part of the peace agreement reached in 1979. In 1981 Israel officially annexed the Syrian Golan Heights.

3. Handel explains that the Palestinian creates his physical and spatial resistance by forbidding himself 'to take paths generally considered accessible or even obligatory' (creating shortcuts and detours to avoid checkpoints for example) (Handel 2009: 215)

4. At the start of the 1980s Meron Benvenisti was the first to diagnose the system of control over the territories as fundamental to the Israeli regime, and pointed to the irreversibility of these changes (see www.matzpen.org).

5. Azoulay and Ophir disassociate their study from the critical tradition that sees Zionism as a colonising fabric, arguing that the occupation is not the inevitable product of a long colonial history (Azoulay and Ophir 2008: 22). Although they are right to refuse to reduce their analysis to assigning the given (the occupation) to existing given categories (Zionist colonialism), and to insist on forging new concepts for evaluating the given - by uncoupling their study from the historical storyline of Zionist colonialism, I believe that they withhold important layers of understanding. The genealogy of Zionist colonialism - to which we have access thanks to pioneering studies by the likes of Shafir (1989), Smith (1993) and Pappe $(1999,2004,2006)$-teaches us about the cultural and political processes we are engaged in. The past always plays a role in the present - 'for example, the consequences of colonisation persist and produce further effects, in social life as well as in the memories of those affected, long after the initial acts of settlement' (Patton 1997: 5). Thus, the colonial past which evolved from the initial Zionist-Palestinian encounter, continues to be evident in the present, playing a role which cannot be ignored. This is because the qualitative difference encapsulated in the Zionist colonial event did not abdicate its position of dominance in the Zionist-Palestinian plane in favour of new differences. Shafir's main thesis in his seminal work on the origins of the Zionist-Palestinian conflict (Shafir 1989) was that the logic of ethnic exclusion adopted by the Zionist settlement at the start of the twentieth century emerged from class struggles in the labour market. At this point, as I have already argued elsewhere (Svirsky 2010), a collective desire producing displacementreplacement began to be assembled (I defined it as a desire for terra nullius). This turning point continues to echo today. In other words, we cannot gain a comprehensive understanding of the occupation regime without taking into account the historical evolution of the colonial event of Zionism, and the ways in which desire has been and is collectively put to work throughout this project. My contention in this context is that the 'appetite' for land and the corresponding effects of expropriation, dispossession and expulsion of Palestinians was already an established and evolving Zionist habit well before 1967.

6. This is the case for example, with the civic-education official curriculum in highschools. The subject of the occupation is treated in the official book in two sections: under the headings 'The national schism' and 'The ideological schism'. In both sections the territories appear with their biblical-recycled-Zionist names, 
Judea and Samaria, and the issue is totally detached from any discussion on the relation of the occupation with the regime of Israel itself, and with its impact on Israeli political culture or ways of life. Most sadly, the connection between the maintenance of the occupation and the role the pupils studying this very book will play in that effort is also absent. (See To Be Citizens in Israel: A Jewish-Democratic State, Jerusalem: Ministry of Education, 1999, pp. 289-90; 332-45).

7. The legal integration of the Palestinians into Israel would have been detrimental to Israel's demographic desire to maintain a clear dominant Jewish majority.

8. The first colony was established as early as 1967. According to the figures published by the Israeli Central Bureau of Statistics, in 2008 the Israeli population in the West Bank colonies totalled 268,900, representing approximately $3.75 \%$ of the total Israeli population.

9. As Azoulay and Ophir explain: 'The Palestinian ceased to be he or she who is subjected to power. His or her existence was reduced to that of a moving body that interests the ruling power' (Azoulay and Ophir 2009: 135).

10. 'In 1970, 5\% of the Palestinian workforce was employed inside Israel or by Israeli employers. By 1987 , over $45 \%$ of the workforce provided $85 \%$ of the Palestinian gross domestic product, which gradually created economic dependence among Palestinians on the possibility of entry into Israel. This was due to a relatively free passage of people and goods to and from the OPT implemented in $1971 \ldots$. [which] come to a temporary halt during the 1991 Gulf war' (and worsen afterwards as a response to the intifadas) (Shenav and Berda 2009: 338)

11. 'By 2007, Palestinian real per-capita income fell by $40 \%$ compared with its 1999 levels, and poverty rates soared to over $67 \%$... Palestinian GDP has fallen by $30 \%$ over the past fifteen years' (Farsakh 2009: 379, 398).

12. In the economic treaties of the Oslo Accords, Israel also secured itself an unfair advantage, while bringing about yet further deterioration of the Palestinian economy (Gordon 2008: 185-7).

13. See http://www.whoprofits.org/index.php. This website shows who profits from the occupation.

14. Illegal or unauthorised outposts, as defined by the Sasson Report of March 2005 (submitted at the request of the Prime Minister's Office), are small settlements in the West Bank (there are more than a hundred) erected during the 1990s after building in the Palestinian territories was frozen by the Rabin administration (following the Oslo Accords). In the absence of an official governmental decision, any establishment of a settlement in the occupied territories is illegal. These outposts were built by groups of West Bank settlers in cooperation with public institutions; the leitmotif of this phenomenon was simply the expansion of the Jewish presence so as to make it impossible to reach a peace agreement.

15. The Oslo agreements defined three types of domination, combining civil control and security: A, B and C. Territories of type A are under Palestinian control (both civil and security); type B fall under Palestinian civil control, with Israel controlling security; and type $\mathrm{C}$ are under total Israeli control. All roads and border crossings remain under Israeli control.

16. I'm aware of Ilan Pappe's critique of using Agamben's paradigm to analyse the occupation (Pappe 2008: 148-70), and I agree that Israel must not be seen as a democratic polity corrupted to include exception for it never was a democracy in any sense. But what is important for me in using Agamben's paradigm is the conceptual framework it provides for analysing relations of abandonment: what characterised them, how are they maintained, by whom, and how they can be transformed. 


\section{The Empty Square of the Occupation 409}

17. Eyal Benvenisti wrote on the legal aspect of the absorption of the occupation. See Benvenisti 1990.

18. Power is that which connects between subjects, objects, practices and systems, transforming them from 'sides' into points of application.

19. I must say that, in a way, Gordon's formula for change (power-excesscontradictions-resistance and back again) appears to be a catch-all explanation for any phenomenon, and thus fails to capture the uniqueness of the event of the occupation.

20. The 'Wall' winding through the West Bank separates not only Israelis from Palestinians, but 'in many areas... actually separates Palestinians from Palestinians' and from their land, in violation of fundamental rights and serving to 'create facts on the ground whose aim is to undercut the Palestinian statebuilding project' and to promote the annexation of lands by Israel (Gordon 2008: 213).

21. Al-Nakbah - Arabic for 'The Calamity' or 'The Catastrophe' - is the Arab name for the Israeli war of independence of 1948-9, when nearly 800,000 Palestinians were expelled from their homes by forces of the nascent Israeli state and their lands seized, destroying about 550 villages and neighbourhoods, and devastating the spine of Palestinian society.

22. For example, the 'Separation Barrier'-in reality, the Wall-through the West Bank affects the Israeli soldiers charged with guarding it: 'the Barrier transforms the soldiers into an effect of its own logic... [becoming] in a sense, an automatic weapon in the service of a concrete wall and a series of trenches and fences' (Gordon 2008: 214-5).

23. See 'The Citizenship and Entry into Israel Law (temporary provision) 5763-2003' at http://www.knesset.gov.il/laws/special/eng/citizenship_law.htm

24. The research and writing of this article was supported by a Marie Curie Intra European Fellowship within the 7th European Community Framework Programme.

\section{References}

Adalah (The Legal Center for Arab Minority Rights in Israel) (2007) The Democratic Constitution, Shafa'amr.

Agamben, Giorgio (1998) Homo Sacer: Sovereign Power and Bare Life, trans. Daniel Heller-Roazen, Stanford: Stanford University Press.

Agamben, Giorgio (2005) States of Exception, trans. Kevin Attel, Chicago: Chicago University Press.

Azoulay, Ariella and Adi Ophir (2008) This Regime Which is Not One: Occupation and Democracy Between the Sea and the River (1967-), Tel Aviv: Resling.

Azoulay, Ariella and Adi Ophir (2009) 'The Order of Violence', in A. Ophir, M. Givoni and S. Hanafi (eds.), The Power of Inclusive Exclusion: Anatomy of Israeli Rule in the Occupied Palestinian Territories, New York: Zone Books, pp. 99-140.

Benvenisti, Eyal (1990) Legal Dualism: The Absorption of the Occupied Territories into Israel, Boulder, CO: Westview Press.

Buchanan, Ian (2008) Deleuze and Guattari's Anti-Oedipus: A Readers Guide, London: Continuum.

Colebrook, Claire (2006) Deleuze: A Guide for the Perplexed, London: Continuum.

Deleuze, Gilles (1988) Bergsonism, trans. Hugh Tomlinson and Barbara Habberjam, New York: Zone Books.

Deleuze, Gilles (1990) The Logic of Sense, trans. Mark Lester with Charles Stivale, ed. Constantin Boundas, New York: Columbia University Press. 


\section{Marcelo Svirsky}

Deleuze, Gilles (1994) Difference and Repetition, trans. Paul Patton, New York: Columbia University Press.

Deleuze, Gilles (1995) 'Control and Becoming', in Negotiations, trans. M. Joughin, New York: Columbia University Press, pp. 169-76.

Deleuze, Gilles (2004) 'How Do We Recognize Structuralism?', in Desert Islands and Other Texts 1953-1974, trans. Michael Taormina, ed. D. Lapoujade, New York: Semiotext(e), pp. 170-93.

Deleuze, Gilles and Félix Guattari (1983) Anti-Oedipus: Capitalism and Schizophrenia, trans. Robert Hurley, Mark Seem and Helen R. Lane, Minneapolis: University of Minnesota Press.

Deleuze, Gilles and Félix Guattari (1987) A Thousand Plateaus: Capitalism and Schizophrenia, trans. Brian Massumi, Minneapolis: University of Minnesota Press.

Deleuze, Gilles and Félix Guattari (1994) What is Philosophy? trans. Hugh Tomlinson and Graham Burchell, New York: Columbia University Press.

Farsakh, Leila (2009) 'From Domination to Destruction: The Palestinian Economy under the Israeli Occupation', in A. Ophir, M. Givoni and S. Hanafii (eds.), The Power of Inclusive Exclusion: Anatomy of Israeli Rule in the Occupied Palestinian Territories, New York: Zone Books, pp. 379-402.

Ghanem, Asad (2001) The Palestinian-Arab minority in Israel, 1948-2000: A Political Study, Albany: State University of New York Press.

Gil, José (2008) O Imperceptível Devir da Imanência-Sobre a Filosofia de Deleuze, Lisboa: Relógio D’Água.

Gordon, Neve (2008) Israel's Occupation, Berkeley: University of California Press.

Handel, Ariel (2009) 'Where, Where to, and When in the Occupied Territories: An Introduction to Geography of Disaster', in A. Ophir, M. Givoni and S. Hanafii (eds.), The Power of Inclusive Exclusion: Anatomy of Israeli Rule in the Occupied Palestinian Territories, New York: Zone Books, pp. 179-222.

Kimmerling, Baruch (1989) 'Boundaries and Frontiers of the Israeli Control System', in B. Kimmerling (ed.), The Israeli State and Society: Boundaries and Frontiers, Albany: State University of New York Press, pp. 265-84.

Lecercle, Jean-Jacques (2002) Deleuze and Language, Great Britain: Palgrave Macmillan.

Lustick, Ian (1980) Arabs in the Jewish State: Israel's control of a National Minority, Austin: University of Texas Press.

Ophir, Adi, Michal Givoni and Sari Hanafi (eds.) (2009) The Power of Inclusive Exclusion: Anatomy of Israeli Rule in the Occupied Palestinian Territories, New York: Zone Books.

Pappe, Ilan (1999) The Israel/Palestine Question, London: Routledge.

Pappe, Ilan (2004) A History of Modern Palestine: One Land, Two Peoples, Cambridge: Cambridge University Press.

Pappe, Ilan (2006) The Ethnic Cleansing of Palestine, Oxford: Oneworld Publications.

Pappe, Ilan (2008) 'The Mukhabarat State of Israel: A State of Oppression is Not a State of Exception', in R. Lentin (ed.), Thinking Palestine, London and New York: Zed Books, pp. 148-70.

Pappe, Ilan (2009) 'The Curse of Partition: Deconstructing the Peace Process in Palestine', paper given at the plenary session of the 'Partitions and Reunification' conference, 15 July 2009, Cardiff University.

Patton, Paul (1997) 'The World Seen From Within: Deleuze and the Philosophy of Events', Theory and Event, 1:1.

Patton, Paul (2007) 'Utopian Political Philosophy: Deleuze and Rawls', Deleuze Studies, 1:1, pp. 41-59. 


\section{The Empty Square of the Occupation 411}

Peled, Yoav and Gershon Shafir (2002) Being Israeli: The Dynamics of Multiple Citizenship, Cambridge: Cambridge University Press.

Raz-Krakotzkin, Amnon (2007) 'The Six-Months State: Israel, Occupation and the Bi-national Perspective', Mahsom, 6 June 2007; http://www.mahsom/article. php?id=5501 (in Hebrew).

Shafir, Gershon (1989) Land, Labour, and the Origins of the Israeli-Palestinian Conflict 1882-1914, Cambridge: Cambridge University Press.

Shenav, Yehouda and Yael Berda (2009) 'The Colonial Foundations of the State of Exception: Juxtaposing the Israeli Occupation of the Palestinian Territories with Colonial Bureaucratic History', in A. Ophir, M. Givoni and S. Hanafi (eds.), The Power of Inclusive Exclusion: Anatomy of Israeli Rule in the Occupied Palestinian Territories, New York: Zone Books, pp. 337-74.

Smooha, Sammy (1990) 'Minority Status in an Ethnic Democracy: The Status of the Arab Minority in Israel', Ethnic and Racial Studies, 13:3, pp. 389-413.

Smooha, Sammy (1997) 'Ethnic Democracy: Israel as an Archetype', Israel Studies, $2: 2$, pp. $198-241$.

Smith, Barbara (1993) The Roots of Separatism in Palestine, London: Tauris.

Svirsky, Marcelo (2010) 'The Desire for Terra Nullius and the Zionist-Palestinian Conflict', in P. Patton and S. Bignall (eds.), Deleuze and the Postcolonial, Edinburgh: Edinburgh University Press.

Weizman, Eyal (2007) Hollow Land: Israel's Architecture of Occupation, London: Verso.

Williams, James (2005) Understanding Poststructuralism, Chesham: Acumen.

Williams, James (2008) Gilles Deleuze's Logic of Sense: A Critical Introduction and Guide, Edinburgh: Edinburgh University Press.

Yiftachel, Oren (1993) 'Power Disparities in the Planning of a Mixed Region: Arabs and Jews in the Galilee, Israel', Urban Studies, 30:1, pp. 157-82.

Yiftachel, Oren (1999) 'Ethnocracy: The Politics of Judaizing Israel/Palestine', Constellations: International Journal of Critical and Democratic Theory, 6:3, pp. 364-90.

Yiftachel, Oren (2006) Ethnocracy: Land and Identity Politics in Israel/Palestine, Philadelphia: University of Pennsylvania Press. 